\title{
Corporate Water Stewardship: Achieving a Sustainable Balance
}

\author{
Joe P Rozza ${ }^{1}$, Brian D Richter ${ }^{2}$, Wendy M Larson ${ }^{3}$, Todd Redder ${ }^{3}$, Kari Vigerstol $^{2} \&$ Paul Bowen $^{1}$ \\ ${ }^{1}$ Department of Safety and Environmental Sustainability, The Coca-Cola Company, Atlanta, Georgia, USA \\ ${ }^{2}$ The Nature Conservancy, Seattle, Washington, USA \\ ${ }^{3}$ LimnoTech, Ann Arbor, Michigan, USA \\ Correspondence: Joe P Rozza, Global Water Resource Sustainability Manager, The Coca-Cola Company, One \\ Coca-Cola Plaza, Atlanta, Georgia 30313, USA. Tel: 1-404-676-4764. E-mail: jrozza@coca-cola.com
}

$\begin{array}{ll}\text { Received: July 10, } 2013 & \text { Accepted: July 29, } 2013 \quad \text { Online Published: November 18, } 2013 \\ \text { doi:10.5539/jms.v3n4p41 } & \text { URL: http://dx.doi.org/10.5539/jms.v3n4p41 }\end{array}$

\begin{abstract}
Globally, corporations and industry are seeking to secure access to sufficient quantities of water to meet current and future needs in a socially, economically and environmentally responsible way in the midst of an unfolding global water crisis with risks that transcend communities, industry and the environment. Through a business case centered on sustainability performance, risk management and productivity and through implementation of a strategic framework based on a water mass balance at the enterprise level, industry can take actions that support restoration of a sustainable water balance at the community and watershed levels while also generating business value for that particular enterprise. Within this framework, the volume of consumptive water use is used to establish the target water volume that an enterprise would balance through implementation of community water partnerships (CWP) that provide water access and sanitation, watershed restoration and protection, and water for productive use benefits. Quantification of CWP project benefits is achieved either through metering or standard methods known and accepted by the engineering, conservation, and social science professions. A $100 \%$ sustainable balance is achieved when an enterprise implements a portfolio of locally relevant CWPs that collectively produce an annual volumetric benefit equivalent to the annual volume of consumptive water use for that particular enterprise.

This approach can also support efforts by industries that seek to operate in a manner consistent with the United Nations resolution regarding the human right to water and sanitation, as well as those that may seek certification under emerging global water stewardship standards.
\end{abstract}

Keywords: water, sustainability, neutrality, strategy, risk, stewardship, human right to water and sanitation, water stewardship certification

\section{Introduction}

The challenges associated with water stewardship in the 21 st century are multidimensional and inter-related. Water resources the world over are under increasing stress due to the combined effects of three significant challenges: population growth, economic development and climate change (Intergovernmental Panel on Climate Change, 2007). These trends, in turn, are driving an imbalance between water supply and demand that is jeopardizing the reliability of water to support human health, agricultural productivity, and economic development, and to maintain sustainable ecosystems (World Economic Forum, 2009). This growing imbalance further manifests into integrated risks to communities, the environment and industry. Resolving this imbalance will require assessment of all water uses from a watershed or aquifer perspective so that the most appropriate remedial solutions can be identified.Yet, many industries pursue water stewardship within the limited scope of actions to manage their direct water use without investing in the sustainability of watersheds and the water sustainability of communities - indicating a lack of understanding of how environmental and social water related risks can adversely impact industry. Furthermore, for growth industries total water use requirements can increase even as they become more efficient with water-and with growing water stress and increasing competition, the ability to access more water is not guaranteed.

A number of leading companies are already engaged in a range of collective actions including improving community access to safe water, sanitation, and hygiene (WASH); promoting better storm water management and flood control, advancing sustainable agriculture; adapting to climate change; ecosystem restoration; 
monitoring, public education; and support for water policy development (CEO Water Mandate, 2012). However, achieving greater scale, increasing industrial participation and maximizing the strategic impact of these collective actions requires an evolution in the business case for these efforts as well as a reliable strategic framework that directly links collective actions that reduce global water risks to the creation of business value.

This paper presents a business case and strategy that reconciles these complex issues into a cohesive framework for industry to achieve a $100 \%$ sustainable water balance (i.e., water neutrality) in a way that creates business value by supporting collective action focused on mitigating growing water stress, strengthening water-climate resiliency, supporting environmental and community sustainability, and sustaining water security for future generations. The approach begins with good stewardship of the water resources industry uses and returns to the environment, and extends to include balancing the fraction of water use that is consumptive through implementation of community and watershed projects that produce volumetric water benefits equal to or greater than the volume of consumptive use (Note 1) for the particular enterprise. These actions can create business value, mitigate risks and contribute to the creation of broader, stronger and more sustainable markets in the future.

\section{A Strategic Approach to Water Stewardship}

For industry, pursuing a sustainable water balance needs to make business sense, therefore an excellent starting point for the development of an industrial water stewardship strategy is to understand how the strategy can enable the mainline growth strategy of the enterprise. An important first step is to assess how water-related risks can impair growth or otherwise adversely impact the enterprise and how improved water stewardship performance can add value. These concepts feed into a business case framed in risk management, productivity and sustainability performance, Figure 1 . These concepts are mutually reinforcing. For example, sustainability performance leads to "lean and green" supply chains which yield productivity gains through cost reductions. Sustainability performance can drive better risk management through cost avoidance, improved water supply reliability and protection of reputation (i.e., maintaining a positive relationship with the surrounding community and water users within a given watershed). With growing consumer preference for sustainably manufactured goods and socially responsible companies, sustainability performance within facilities, communities and watersheds can also be leveraged as a company or product differentiator in competitive markets.

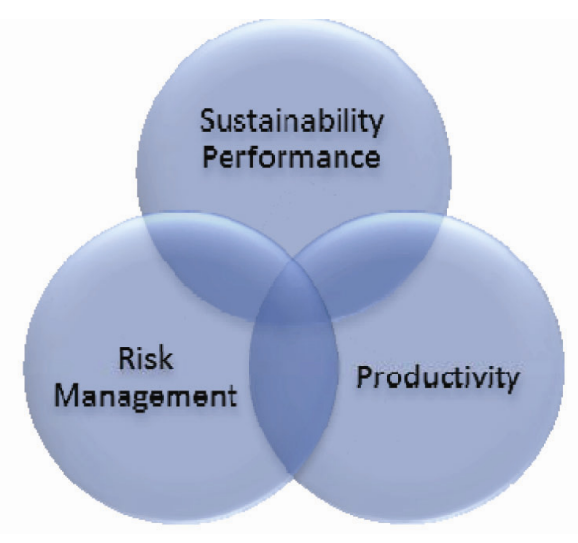

Figure 1. Redefined business case for water stewardship

The strategic aim of achieving a sustainable balance is to return to communities and nature a volume of water equivalent to or greater than what the enterprise uses in its manufacturing process and in its products. Water stewardship and social responsibility are required through the entire water cycle for the enterprise's direct operations - from its sources of water through manufacturing processes and relative to the manufactured good. An effective industrial water stewardship strategy can be shown in the form of a water mass balance at the enterprise level, Figure 2. This framework illustrates how priorities and programs work synergistically to achieve a sustainable balance and greater degrees of more strategically significant social responsibility. 


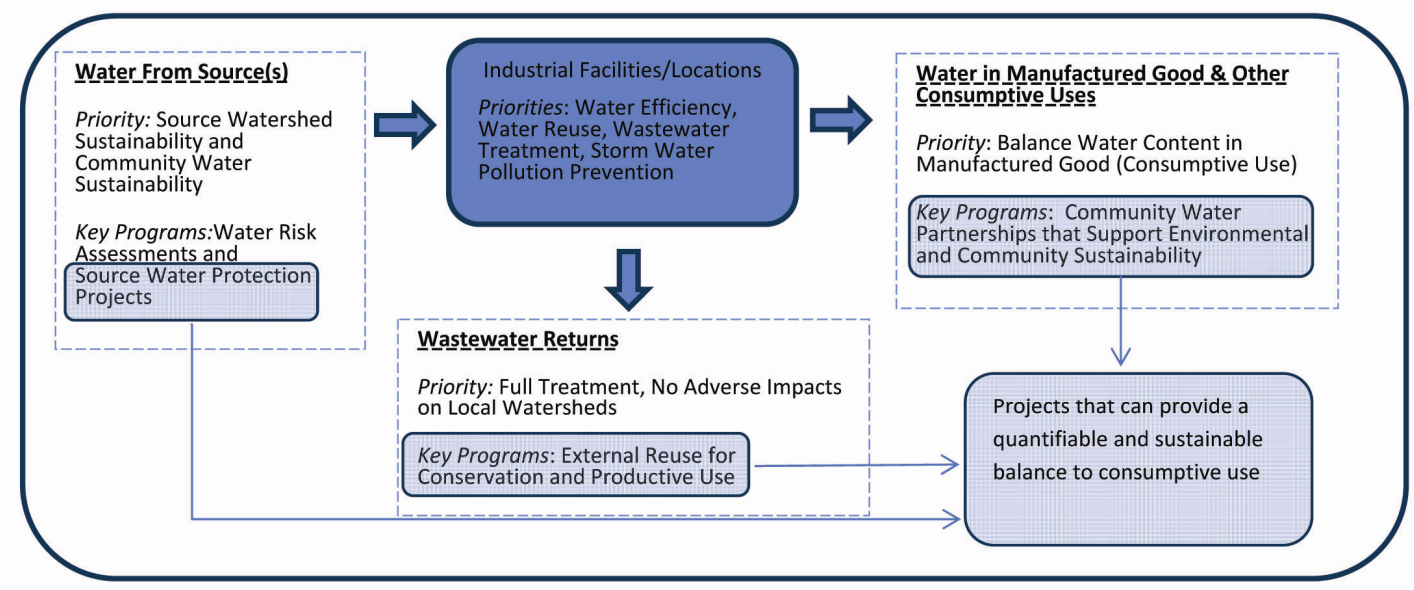

Figure 2. Framework for achieving a sustainable water balance

\subsection{Stewardship of Water Sources}

For most industries, their business is only as sustainable as the communities and watersheds where they operate and that of the markets for their goods and services. Understanding the stressors and risks that jeopardize watershed and ecosystem sustainability, and undermine community sustainability is essential to designing source water protection programs that benefit both communities and nature. For a water risk assessment to be effective and drive strategic investments, it needs to be tailored to the specific industry and should cover the following considerations (at a minimum):

- Water Resource Sustainability and Supply Reliability—Factors include:

- Environmental sustainability of the water source (quantity, quality, and ecosystems)

- Local public sector water resource management capacity

- Social water equity (access to safe drinking water and proper sanitation)

$\circ \quad$ Water resource management policy

- Climate change adaptation capability

- Water infrastructure condition and funding policy

○ Natural disaster potential (e.g., floods, droughts, hurricanes)

- Water Efficiency and Economics-Factors include efficiency, cost of water use (acquisition and treatment), cost of source water protection, and assessment of current and future water needs and intensity.

- Wastewater Treatment-Factors include compliance with local regulations, reliable treatment system operation and confirmation that wastewater discharges are not adversely impacting local watersheds.

- Local Relationship-Factors include the relationship between the facility and the local community, government, NGOs, and media awareness and reporting on water issues. The degree of collaboration among local industry should also be assessed.

Risk assessments can be combined with local stakeholder engagement to create multi-year source water protection plans (SWP Plans) designed to address priority risks and support the sustainability of water resources and communities. During the assessment it is critical to ensure that the industrial facility's water use and discharge of wastewater do not have an adverse impact on the sustainability of local water resources or the local community's ability to affordably access the water it needs. SWP Plans can, and should, include community water partnership projects that either protect and restore watersheds, help close a water access or sanitation gap or leverage water for other social and economic development outcomes (if the water can be sourced sustainability). As further explained below, SWP Plans should identify actions that increase water stewardship efforts at the manufacturing plant (e.g., water efficiency for risk management) which may not satisfy pure financial return on investment requirements (i.e., simple payback). 


\subsection{Water Stewardship at Site Locations, Including Wastewater Returns}

Industry can drive investments in site level water stewardship with much greater strategic impact by leveraging the insights from multi-dimensional water risk assessments and by adopting the redefined business case, Figure 1 . Investments in water use efficiency, wastewater treatment, wastewater reuse and storm water pollution prevention can be designed to achieve environmental and social risk mitigation as well as capture productivity value in terms of cost reductions and avoidance. In water stressed areas, if the traditional simple payback method of decision making were to be used instead of the integrated approach (Figure 1) certain industries could inadequately manage business risks and miss productivity opportunities. These risks are amplified for industries with high water dependence and capital intensive business growth.

The water stewardship approach at the facility level should pursue the synergies between water efficiency, wastewater treatment and wastewater reuse. Increasing efficiency reduces the capacity requirements and operating expenses of water and wastewater treatment processes. More effective and reliable wastewater treatment enables greater degrees of reuse, which drives water use efficiency performance. Water stewardship at the facility level also must ensure that both wastewater discharges and storm water runoff are not having an adverse impact on local watersheds either from a quantity or quality perspective. When wastewater is reliably treated to levels safe for reuse it represents water equity that can be leveraged to support environmental conservation (e.g., wetland restoration, aquifer recharge), improve local water efficiency and for productive uses that support economic development (e.g., agricultural productivity). The barriers to greater degrees of wastewater reuse are not technological; they are organizational capability, policy, infrastructure, and public awareness and acceptance.

\subsection{Balancing Consumptive Uses of Water}

The total water requirements for many water dependent industries will continue to rise even with significant improvements in water efficiency. Additionally, water use efficiency improvements do not address or compensate for consumptive uses including losses of water through evaporative processes (e.g., cooling towers) and water retained in the manufactured good (e.g., beverages). To achieve a sustainable water balance the volume of water used in industrial processes and retained in the final manufactured good must be returned to nature and communities. This balance is achieved through the return of clean water back to the environment, through comprehensive wastewater treatment,and implementation of community water partnership projects that produce a volumetric water benefit equal to or greater than the volume of consumptive use. Balancing consumptive water use can occur within the watershed and community where consumptive use occurs or in other areas where the need is greater.

The commitment to achieve a sustainable balance is long-term since the community water partnership project portfolio must continue to grow commensurate to the increase in consumptive use. Effectively meeting this commitment requires decision support to remove uncertainty during planning and ensure that investments achieve the intended social, environmental and business objectives, in a sustained fashion, while at the same time providing quantifiable benefits that balance consumptive water use. The following types of community water partnership projects can be used to balance consumptive water use:

- Watershed Protection and Restoration

- Water Access and Sanitation

- Water for Productive Use

Public education and awareness programs, as well as business engagement on water policy reform are also critical business responses to water risks and challenges. However, regardless of how important such engagements are, the beneficial water balance contributions from such efforts cannot reliably be quantified due to several factors including the numerous stakeholders and partners involved in such efforts.

Balancing consumptive water use through implementation of community water partnership projects typically would require an augmentation to the direct community/watershed interventions and philanthropic support of communities and nature that industry elects to provide. Justifying increased and/or modified investments is accomplished by developing the business case around the principles of productivity, risk management and sustainability performance (Figure 1).

\subsubsection{Watershed Protection and Restoration}

These projects present the opportunity to reduce risks to communities, nature and industry; they are intended to improve watershed conditions and functionality in support of ecosystems, communities and economies 
dependent on them. They typically include policy, planning, and implementation of better practices that protect sensitive watershed resources and restore resources degraded due to urbanization, agriculture and other factors (Center for Watershed Protection, 2013). Volumetric water benefits can be estimated using a suite of standard empirical and process-based watershed management methods, Table 1. Empirical methods, for example the NRCS Runoff Curve Number method (United States Department of Agriculture, 1986) are used to estimate the overall reduction or improvement in runoff. Process-based methods,for example as employed in the Soil and Water Assessment Tool (Neitsch, et al., USDA Agricultural Research Service and Texas A\&M University, 2005), are used to estimate other types of metrics, including the changes in storage and losses of water through processes such as evapotranspiration. The volumetric water benefit of these projects that would be counted as a balance to consumptive use is the annualized volume of water that is restored to a more natural condition within the watershed after the project as compared to the pre-project condition.

Table 1. Community water partnership project categories, objectives and benefit quantification methods

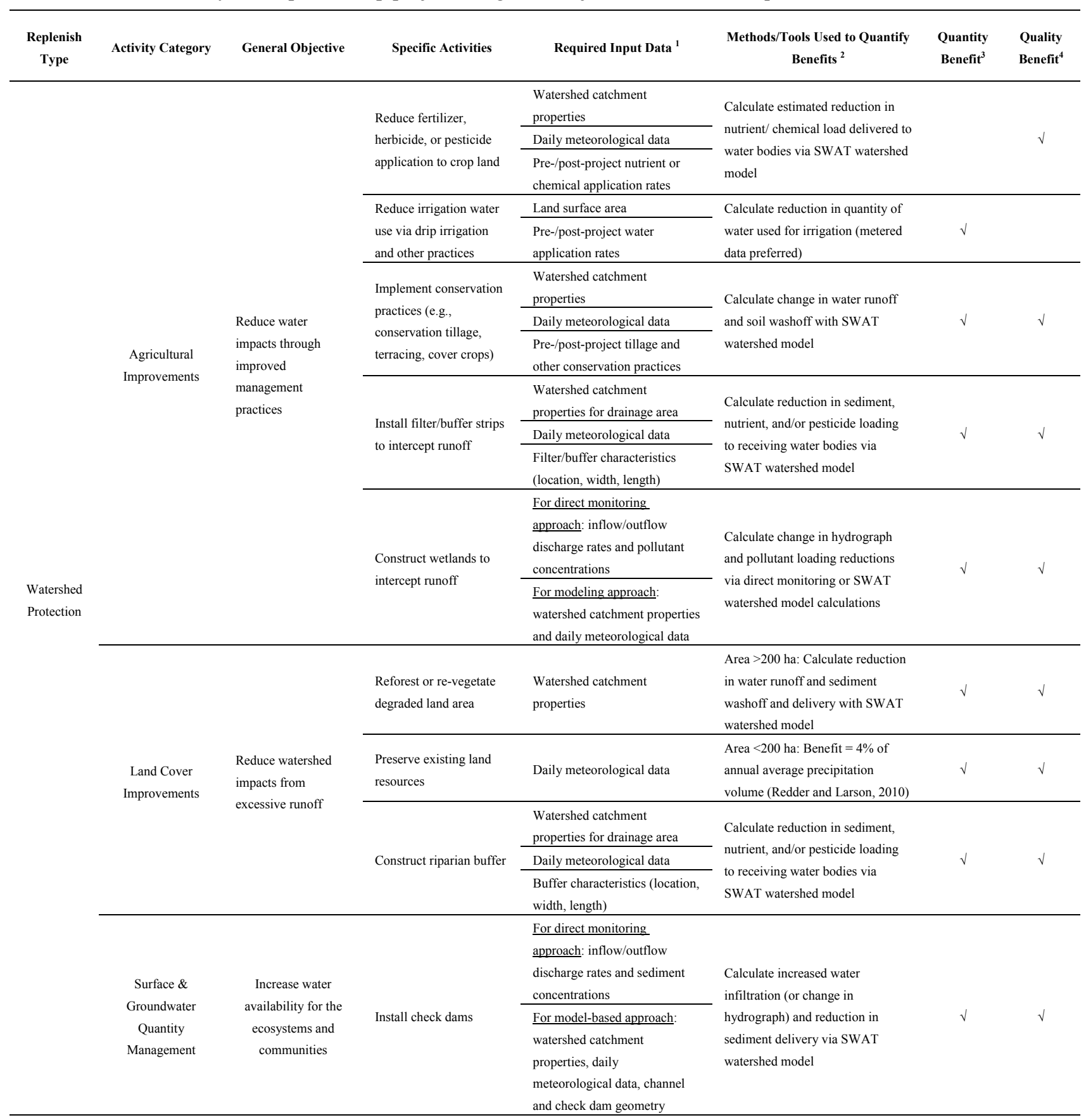




\begin{tabular}{|c|c|c|c|c|c|c|c|}
\hline & & & \multirow{2}{*}{$\begin{array}{l}\text { Reconnect water body to } \\
\text { floodplain or block } \\
\text { drainage structures to } \\
\text { restore storage capacity } \\
\end{array}$} & Surface area of wetland & \multirow[b]{2}{*}{$\begin{array}{l}\text { Calculate typical annual volume of } \\
\text { restored wetland inundation }\end{array}$} & \multirow[b]{2}{*}{$\sqrt{ }$} & \\
\hline & & & & $\begin{array}{l}\text { Volume and frequency of } \\
\text { inundation }\end{array}$ & & & \\
\hline & & & $\begin{array}{l}\text { Water transfers to } \\
\text { protect environmental } \\
\text { flows }\end{array}$ & $\begin{array}{l}\text { Documented volume of flow } \\
\text { transferred }\end{array}$ & Direct metering of transferred flow & $\sqrt{ }$ & \\
\hline & & & \multirow{3}{*}{$\begin{array}{l}\text { Rainwater harvesting } \\
\text { and aquifer recharge }\end{array}$} & $\begin{array}{l}\text { Typical/average monthly } \\
\text { precipitation }\end{array}$ & \multirow{3}{*}{$\begin{array}{l}\text { "TCCC Rainwater Harvesting } \\
\text { Model" }\end{array}$} & \multirow{3}{*}{$\checkmark$} & \\
\hline & & & & $\begin{array}{l}\text { Collection \& storage system } \\
\text { characteristics (surface area, } \\
\text { etc.) }\end{array}$ & & & \\
\hline & & & & $\begin{array}{l}\text { Aquifer recharge system } \\
\text { characteristics (maintenance, } \\
\text { etc.) }\end{array}$ & & & \\
\hline & & & Stormwater management & $\begin{array}{l}\text { Watershed catchment } \\
\text { properties (i.e., land surface } \\
\text { area) }\end{array}$ & \multirow{3}{*}{$\begin{array}{l}\text { Calculate change in runoff } \\
\text { hydrograph and sediment and/or } \\
\text { nutrient washoff loadings with } \\
\text { SWAT watershed model }\end{array}$} & \multirow{3}{*}{$\sqrt{ }$} & \multirow{3}{*}{$\sqrt{ }$} \\
\hline & & & $\begin{array}{l}\text { (e.g., rain gardens, rain } \\
\text { barrels, detention basins) }\end{array}$ & Daily meteorological data & & & \\
\hline & & & & $\begin{array}{l}\text { Structure characteristics } \\
\text { (location, surface area, storage } \\
\text { capacity) }\end{array}$ & & & \\
\hline & & & & Surface area for removal & & & \\
\hline & & & $\begin{array}{l}\text { Biologic management } \\
\text { (removal of 'thirsty' } \\
\text { invasive species) }\end{array}$ & $\begin{array}{l}\text { Water consumption rate for } \\
\text { invasive species (pre-project) } \\
\text { and native vegetation } \\
\text { (post-project) }\end{array}$ & $\begin{array}{l}\text { Calculation of change in annual } \\
\text { uptake and evapotranspiration } \\
\text { losses }\end{array}$ & $\sqrt{ }$ & \\
\hline & \multirow[b]{2}{*}{$\begin{array}{c}\text { Treatment of } \\
\text { Polluted Discharge }\end{array}$} & \multirow[b]{2}{*}{$\begin{array}{c}\text { Improve water } \\
\text { quality of receiving } \\
\text { water }\end{array}$} & \multirow[b]{2}{*}{$\begin{array}{l}\text { Construct treatment } \\
\text { wetland or wastewater } \\
\text { treatment plant }\end{array}$} & $\begin{array}{l}\text { Average discharge rate of } \\
\text { treated water from treatment } \\
\text { system (post-project) }\end{array}$ & $\begin{array}{l}\text { 1. Calculate water quantity } \\
\text { benefit as the discharge rate from } \\
\text { treatment system }\end{array}$ & $\sqrt{ }$ & $\sqrt{ }$ \\
\hline & & & & $\begin{array}{l}\text { Treatment type or effluent } \\
\text { monitoring data }\end{array}$ & $\begin{array}{l}\text { 2. Calculate water quality } \\
\text { benefit as difference between pre } \\
\text { and post-project pollutant loads } \\
\text { based on type of treatment or } \\
\text { monitoring data }\end{array}$ & $\sqrt{ }$ & $\sqrt{ }$ \\
\hline \multirow{3}{*}{$\begin{array}{l}\text { Water for } \\
\text { Productive } \\
\text { Use }\end{array}$} & Agricultural & $\begin{array}{l}\text { Provide water to } \\
\text { promote crop } \\
\text { production }\end{array}$ & $\begin{array}{l}\text { Increase water supply for } \\
\text { irrigation use }\end{array}$ & $\begin{array}{l}\text { Pre and post-project irrigation } \\
\text { water use (e.g., million liters } \\
\text { per hectare per year) }\end{array}$ & $\begin{array}{l}\text { Calculate increase in annual } \\
\text { volume of irrigation water use } \\
\text { relative to pre-project condition }\end{array}$ & $\sqrt{ }$ & \\
\hline & Water Reuse & $\begin{array}{l}\text { Provide water to } \\
\text { community for } \\
\text { economic benefit }\end{array}$ & $\begin{array}{l}\text { Reuse treated process } \\
\text { water from plant for } \\
\text { industry or irrigation }\end{array}$ & $\begin{array}{l}\text { Volume of water reused per } \\
\text { year and purpose }\end{array}$ & $\begin{array}{l}\text { Calculate annual volume of water } \\
\text { reused }\end{array}$ & $\sqrt{ }$ & \\
\hline & $\begin{array}{c}\text { Water } \\
\text { Conservation }\end{array}$ & $\begin{array}{l}\text { Reduce water losses } \\
\text { (e.g., leak repairs) }\end{array}$ & $\begin{array}{l}\text { Reduce water } \\
\text { withdrawals via } \\
\text { infrastructure upgrades }\end{array}$ & $\begin{array}{l}\text { Water savings based on } \\
\text { metering data or estimates of } \\
\text { pre-/post-project usage }\end{array}$ & $\begin{array}{l}\text { Calculate water savings based on } \\
\text { direct metering data for source } \\
\text { water body }\end{array}$ & $\sqrt{ }$ & \\
\hline \multirow{4}{*}{$\begin{array}{l}\text { Water } \\
\text { Access }\end{array}$} & $\begin{array}{l}\text { Groundwater } \\
\text { Access }\end{array}$ & \multirow{4}{*}{$\begin{array}{l}\text { Increase delivery of } \\
\text { water to communities } \\
\text { for drinking water } \\
\text { and sanitation }\end{array}$} & $\begin{array}{l}\text { Boreholes, well } \\
\text { construction / } \\
\text { rehabilitation, protected } \\
\text { spring box, other }\end{array}$ & $\begin{array}{l}\text { 1. Metering data (preferred), or } \\
\text { 2. Number of direct }\end{array}$ & \multirow{2}{*}{$\begin{array}{l}\text { 1. Direct metering (preferred), or } \\
\text { 2. World Health Organization's } \\
\text { "reasonable access" standard ( } 20 \\
\text { L/ person/day within } 1 \mathrm{~km} \text { of } \\
\text { person's dwelling) applied to } \\
\text { number of direct beneficiaries }\end{array}$} & $\sqrt{ }$ & \\
\hline & $\begin{array}{l}\text { Distribution } \\
\text { Network } \\
\text { Construction } \\
\end{array}$ & & $\begin{array}{l}\text { Water distribution } \\
\text { network construction / } \\
\text { rehabilitation }\end{array}$ & beneficiaries with full access & & $\sqrt{ }$ & \\
\hline & \multirow{2}{*}{$\begin{array}{l}\text { Rainwater } \\
\text { Harvesting }\end{array}$} & & \multirow[b]{2}{*}{ Rainwater harvesting } & $\begin{array}{l}\text { Typical/average monthly } \\
\text { precipitation }\end{array}$ & \multirow{2}{*}{$\begin{array}{l}\text { Calculate water supply to } \\
\text { community via the "TCCC } \\
\text { Rainwater Harvesting Model" }\end{array}$} & \multirow{2}{*}{\multicolumn{2}{|c|}{$\sqrt{ }$}} \\
\hline & & & & $\begin{array}{l}\text { Collection \& storage system } \\
\text { characteristics (surface area, } \\
\text { etc.) }\end{array}$ & & & \\
\hline \multicolumn{8}{|c|}{$\begin{array}{l}1 \text { "Watershed catchment properties" includes the following: location (latitude/longitude), land surface area affected, land slope, soil drainage properties, and pre- and post-project land } \\
\text { use/cover characteristics. "Meteorological data" refers to precipitation, air temperature, and possibly other climate parameters at the specified time scale (e.g., daily, monthly, or annual). } \\
{ }^{2} \text { The SWAT ("Soil \& Water Assessment Tool") model (Neitsch et al. 2005) is capable of estimating daily water runoff via the Curve Number method (USDA-NRCS 1986), daily sediment } \\
\text { washoff and delivery via the "Modified Universal Soil Loss Equation" (MUSLE) (Williams 1975), and daily washoff and delivery of other pollutants (nutrients, pesticides, etc.). The } \\
\text { model is available from the official SWAT website: http://swatmodel.tamu.edu/software/swat-model. The "TCCC Rainwater Harvesting Model" is a spreadsheet-based model that is } \\
\text { available on the GWS website (https://www.tcccgws.com/gws/login/login.asp). } \\
{ }^{3} \text { Water quantity benefits are expressed in units of million liters per year (ML/yr). }\end{array}$} \\
\hline
\end{tabular}




\section{References:}

Neitsch, S.L., J.G. Arnold, J.R. Kiniry, and J.R. Williams. 2005. "Soil and Water Assessment Tool Theoretical Documentation: Version 2005.” January.

Redder, Todd and W. Larson. May 2012. Review of a Simplified Alternative Approach for Estimating Water Quantity Benefits for Land Use / Land Cover (LU/LC) Alteration Activities.

Memorandum to Joe Rozza.

USDA-NRCS. 1986. "Urban Hydrology for Small Watersheds-Technical Release 55 (TR-55)." $2^{\text {nd }}$ Edition.

Williams J.R. 1975. "Sediment yield prediction with USLE using runoff energy factor.” In: ARS-S-40. Agr. Res. Serv., USDA. Washington DC. pp. $244-252$.

Addressing source water vulnerabilities, mitigating business risks, and achieving a sustainable balance typically must also accommodate water quality improvements, as degraded water quality is a pervasive challenge to water resource sustainability and a significant risk to human health globally. Many watershed projects are directed at reducing sedimentation, a ubiquitous problem globally. The mass of sediment that no longer leaves the land, after successful project implementation can be estimated using the Modified Universal Soil Loss Equation (MUSLE) method as implemented within the Soil \& Water Assessment (SWAT) model. In these cases, the focus is on the quality of storm water runoff or runoff from irrigated land. The basis for estimating the volume of water to count as a balance to consumptive use is the volume of water runoff treated to achieve a pollutant load reduction such that the discharge from the area under improved management achieves a pre-defined target concentration. The treatment target must be selected based on a number of factors, including the designated use of the receiving surface water body, existing regulations and any specific load reduction targets that may be established for the watershed. There are a myriad of methods and tools for estimating changes in water quality within a watershed system. Method selection must factor in the specific water quality parameters, data requirements, spatial and temporal scale.

In relation to the water stewardship framework, described in Figure 2, watershed protection and restoration projects can be implemented as source water protection for the industry and/or as community water partnerships. Source water risk assessments identify the locations where watersheds may not be sustainable and would help determine if a water quantity or water quality intervention would be the most beneficial. Outside of the watersheds where the industry is present, the enterprise can elect to engage in community water partnerships projects in partnership with conservation partners, local communities and governments, and development aid agencies.

\subsubsection{Water Access and Sanitation}

These projects are intended to support the health and sustainability of people in communities lacking access to safe drinking water and proper sanitation. Additionally, they can include policy, public sector capacity building, community education and awareness. Quantifiable benefits that balance consumptive use are based on the volumetric service delivery - either metered (preferred) or estimated based on intended number of beneficiaries. If the water access project isn't metered, benefits can be estimated using the World Health Organizations guideline of 20 liters per day per capita as the basic water need for hydration and hygiene (World Health Organization, 2013). For sanitation projects, the volume of treated wastewater is used as the balance to consumptive use.

Water access and sanitation projects can be performed either in support of source water protection and/or as community water partnerships. These projects, when designed with strong community engagement in the local watershed and community of the industrial facility, achieve a measure of social risk mitigation by addressing water access equity concerns at the local level. Water access and sanitation projects also drive sustainability performance because both are essential elements of human and economic development.This type of sustainability performance pursues long view productivity benefits as they contribute to the eventual creation of broader, more vibrant and sustainable markets.

In most cases water access and improved sanitation projects result in an actual increase in local water use and it may seem counterintuitive to pursue these types of projects as a balance to industrial consumptive use. This potential conflict is reconciled by first recognizing that water is a resource (not a pollutant) and that there is nothing inherently wrong with using water, so long as it is done equitably and sustainably. And secondly, within the sustainable water balance framework, Figure 2, balancing consumptive use through CWPs is intended to support restoration of a more sustainable balance between water supply and demand while addressing social, economic and environmental risks - and clearly water access and sanitation is a major social and public health risk.

Enabling water access and sanitation projects to count as a balance to consumptive use is critical in light of the United Nations resolution acknowledging water access and sanitation as a basic human right (United Nations Resolution 64/292). Industries seeking to engage in provision of water access and sanitation must place emphasis 
on the requirement during water risk assessments to ensure water sources are sustainable and industrial water use, as well as wastewater and stormwater discharge, at the local site level is not having an adverse impact on local water supplies or limiting community access to reliable water supplies. Confirming no adverse impacts on watersheds or community access to water is a way to demonstrate industrial respect for water as a basic human need.

Although consumptive water use is eventually returned to the hydrologic cycle, it typically renders that fraction of water unavailable at the local level. As such, consumptive water use is a logical basis to determine the level of industrial participation in the provision of water access and sanitation; the fraction of consumptive use balanced by these projects being a function of the degree to which the enterprise operates in underserved communities and the connection of human health to their overall business strategy and priorities.

\subsubsection{Water for Productive Use}

Water for productive use projects focus on improving the efficiency and/or sustainability of water use in the community and watershed such that water stress can be relieved or water made available for human and economic development. A good example is improving the efficiency of agricultural irrigation by converting from flood to drip irrigation. Care must be taken to assure that - even though water use is more efficient - the scale of water dependent operations are not increased post project such that total water use increases beyond the point of source water sustainability. Other examples include supporting leak detection and repair in municipal water distribution systems, rain water harvesting and leveraging reuse of treated wastewater for environmental conservation and water use efficiency.

Quantification of volumetric water benefits to estimate the balance of consumptive use can be achieved either through metering (preferred) or through engineering estimates of the difference between pre- and post- project water use. Note that similar to water access projects, certain types of water for productive use projects result in an actual increase in water use and in a similar way (as explained above) the dilemma can be reconciled when considered in the context of the broader water stewardship approach, Figure 2. Two additional requirements are necessary to credibly count these projects as a balance to industrial consumptive use: 1) the water source must be sustainable and not adversely impacted by the additional use; and 2) good water stewardship practices prevail from the source through the use of the water and its ultimate reintroduction back to the environment.

Water for productive use projects drive sustainability performance because they support human and economic development and strengthen resiliency to climate change impacts in a way that improves the livelihood of the target communities and does not adversely impact the environment. Similar to water access and sanitation projects, water for productive use projects are a longer-term play that drive productivity benefits because they also contribute to the eventual creation of broader and more vibrant markets in the future.

\subsubsection{Public Education and Awareness}

Public education and awareness projects, as well as business engagement in water policy reform, are designed to build community and local stakeholder awareness of issues that jeopardize environmental and water supply sustainability, build local capability to improve the sustainability of the environment and water supplies, and institutionalize necessary policies. Such projects can be stand alone, but within the context of the water stewardship strategy, Figure 2, they are critical enablers that are best leveraged in support of water access and sanitation, watershed protection/restoration, or water for productive use projects. As stand-alone projects, these efforts typically do not provide quantifiable benefits that can be counted as a balance to consumptive use.

These types of projects can provide social risk mitigation benefits by investing and being visibly engaged in supporting the sustainability of the local community and environment. From a sustainability performance perspective stronger, more capable local governments and communities are better positioned to scale projects and ideas that support local sustainability objectives.

Adoption of the water stewardship strategy, Figure 2, inclusive of the commitment to achieve a sustainable balance of consumptive use presents a new risk that can be managed through public education and awareness - failure of community water partnership projects funded by the enterprise. The modes of project failure are varied but include lack of local capability, insufficient funding, and unreliable supply chains to successfully operate and maintain the new asset and keep it in long term productive service. For organizations seeking to balance consumptive use through community water partnerships, project failure results in a loss of the volumetric balance that project was providing. Risk of project failure is mitigated when public education and awareness builds local capability to successfully transition project ownership to the local government or community and keep the project in long-term productive service. 


\subsection{Project Selection and Quantifying Benefits to Balance Consumptive Use}

A common strategy execution challenge is selecting a project that is locally relevant, supportive to the strategy and has quantifiable benefits. A decision support matrix of projects was developed by The Coca-Cola Company (Rozza, J. P., 2012) as a tool for use during project selection (Addendum 1). This tool, in combination with the more important steps of watershed/community assessments and local stakeholder collaboration, helps ensure projects will have a meaningful impact. The best project can be one that does not have quantifiable benefits - these projects should be implemented even though they may not contribute to quantitatively balancing consumptive use.

The technical philosophy for quantifying the benefits of the various types of projects was presented as each was introduced. The computational methods to quantify benefits are long standing methods known, accepted and in common use within the profession of watershed management and the water stewardship strategy presented above relies upon the specific parameters these methods were developed to evaluate. The innovation is in the interpretation of the various model outputs as a balance to consumptive use for projects implemented within the water stewardship strategy presented above (Figure 2). Table 1 was developed as a tool for practitioners to aid in selecting a method for benefit estimates.

\subsection{Guiding Principles}

Achieving a sustainable balance through the water stewardship strategy in Figure 2 can redefine the role of industry in the global effort to meet the complex environmental, social and economic water-related challenges ahead. During implementation strategic, technical and philosophical questions will arise that have to be answered to maintain strategic focus. The following set of guiding principles has been designed to aid in this regard:

- Projects must be locally relevant in terms of stakeholder and environmental needs. Whether or not a project will produce quantifiable benefits is secondary to ensuring that projects meet local needs.

- Projects must be directed at the sustainable and equitable use of water.

- Water stewardship and balancing consumptive use is a sustainability, risk management and productivity initiative not a literal mass balance. There are some projects that lead to an increase in water use (e.g., water access, conversion of cultivated land from rain-fed to irrigated). Prior to increases in water use, assurances must be made regarding the sustainability of the water source.

- Achieving a $100 \%$ sustainable water balance is a way to achieve water neutrality; which is a distinctly different concept compared to achieving carbon neutrality. The way to achieve carbon neutrality is to reduce and offset carbon emissions such that, on balance, a particular enterprise emits no carbon. This type of neutrality is appropriately applied in climate change strategies because carbon emissions have a global impact through the increase and accumulation of greenhouse gases in the atmosphere and resultant global warming. Conversely, water is a resource not a pollutant and there is nothing inherently wrong with using water-if it is done equitably and sustainably

- Sustainable balance of consumptive use can be implemented in watersheds and communities where a particular enterprise has operations and in watersheds and communities where they are not present. The geographic locations of enterprises do not always correlate geographically to the locations of watersheds and communities with the greatest need. For example, the enterprise may operate a facility in a location where water stress is not of concern, negating the need for a project in that facility's watershed or community. But that facility's managers can contribute to the overall water stewardship strategy of the enterprise by supporting a sustainable water balance project in another location in need of help, such as one within their supply chain geographies or in more distant markets for their goods and services. Enterprises can rely upon information from risk and source water vulnerability assessments within watersheds and communities where they operate as well as guidance and priorities of key conservation partners, development aid agencies, as well as local and regional governments and communities.

\section{Discussion and Conclusions}

Defining a water stewardship strategy for industry to achieve a sustainable water balance of its direct water use, including consumptive use, in a way that supports the interconnected and shared interests of government, civil society, business and the environment was the primary objective of this paper. Inherent in this strategy is a redefined role for industry in the ongoing global efforts to mitigate the growing water-related risks to society, business and the environment due to the growing supply-demand imbalance being driven by population growth, economic development and climate change. This approach also offers a rational basis for industry to establish 
an enterprise level target for the aggregate, measureable benefits of community water partnership investmentsconsumptive water use. Ensuring that the enterprise is improving water efficiency and is not adversely impacting watersheds and communities with its water use, wastewater discharges and storm water runoff are all critical pre-requisites.

Social and environmental water related risks to industry are growing, industrial water rights are often not clear and the ability to increase water use may be uncertain in many geographies. Balancing consumptive use through strategically designed community water partnerships strengthens sustainability of water sources for all users as well as the enterprise's social license to the water it needs. Furthermore, when evaluated in the context of the redefined business case framed by risk management, productivity, and sustainability performance, the presented strategy and approach create the opportunity for industry to more clearly draw the connection between corporate water stewardship, the water challenges facing society, business and the environment with the mainline growth strategy of the enterprise. Quantification of project benefits employs standard engineering, social science, and watershed management equations and tools in common use globally by trained professionals. The use of these existing technical methodologies strengthens the overall approach, since new methods do not need to be developed.

The strategy also creates important incentives. The first is to improve water use efficiency and to reduce the fraction of consumptive use that is not physically part of the manufactured goods or services, so that the sustainable balance target is lessened. The second, by keying the achievement of a sustainable balance to the volumetric benefits of community water partnerships, project funders are incentivized to ensure projects do not fail and that they remain in productive service so that they can continue to count the annual project benefits as a balance to consumptive use, thereby making it necessary to plan for building local capability to manage the project and make the necessary investments in operation and maintenance.

This approach can also support efforts for industries that seek to operate in a manner consistent with the United Nations resolution regarding the human right to water and sanitation and the associated core principles that define the roles for government and industry-protect, respect and remedy-also known as the"Ruggie Principles" (United Nations, Office of the High Commissioner for Human Rights, A/HRC/17/13). According to the resolution, industry is responsible for respecting water as a human right. The presented strategy is consistent with the resolution by ensuring that the enterprise's water use does not adversely impact local watersheds and that it does not impair local community's ability to access the water it needs for hydration and hygiene. Both government and industry are expected to remedy the water and sanitation gap, and the presented strategy creates a mechanism (consumptive use) and a model business case to determine the optimal participation level for the particular enterprise. The strategy is also consistent with the UN Global Compact's CEO Water Mandate's Principles for Responsible Engagement in Water Policy (CEO Water Mandate, 2012): to advance sustainable water management; respect public and private roles; strive for inclusiveness and partnerships; be pragmatic and consider integrated engagement; and be accountable and transparent.

Finally, the strategy is aligned with the Alliance for Water Stewardship's draft International Water Stewardship Standard (IWSS), which is designed to drive water stewardship across all sectors (AWS, 2013). The IWSS is structured based on the recognition that "good water stewards understand their own water use, catchment context and shared risk in terms of water governance, water balance, water quality and important water related areas, then engage in meaningful individual and collective actions that benefit people and nature." Parties seeking IWSS certification will be required to demonstrate water management at the site level as well as collaborative actions beyond property boundaries. Additionally, many of the actions taken through implementation of the presented strategy and approach would support external disclosures and reporting (e.g., CDP Water Disclosure).

There are two key recommendations for improving the strategy. The first is to explore the carbon-water synergies and tradeoffs. For example, in many cases (beyond a certain point) improving water efficiency may require an increase in energy intensity. There is also a potential for quantifiable water benefits to be derived from energy efficiency improvements since the majority of global electrical power generation employs water intensive methods (thermal, nuclear and hydropower). Additionally, there remains the opportunity to better understand how the different types of the community water partnerships can be viewed as adaptation to, and resiliency actions against, climate change, and how these projects could be designed to achieve both mitigation and adaptation objectives. For example, reforestation provides both mitigation through carbon capture and storage, but can also provide quantitative water benefits through increased aquifer storage and recharge. 
The second recommendation for improvement is to expand the scope of the strategy, Figure 2, to encompass the entire value chain of the enterprise, inclusive of inputs to manufacturing and the end use of manufactured goods or water impacts from services provided by a business.

Water pervades and supports all aspects of humanity and ecology in a remarkably complex and integrated 'system of systems'. The integrated risks experienced by government, civil society and industry drive the need for collective action among these stakeholders to meet the growing global demand for water while also addressing the significant social, economic and environmental risks caused by management failures of the past, population growth, economic development and climate change. The way to address these challenges is through collective action focused on restoring and maintaining a sustainable balance.

\section{Acknowledgements}

The authors would like to recognize and thank the following individuals for their editorial support of this paper: Greg Koch, Director of Water Stewardship-The Coca-Cola Company, Vail Thorne, Senior Council-The Coca-Cola Company, Serena Levy, Director of Communications-The Coca-Cola Company and Michelle Bernhart, President-True Blue Communications.

\section{References}

Alliance for Water Stewardship. (2013). The AWS International Water Stewardship Standard: Beta Version for Stakeholder Input and field Testing. Retrieved from http://www.allianceforwaterstewardship.org/Beta\%20AWS\%20Standard\%2004_03_2013.pdf

CEO Water Mandate. (2012). Guide to Water-Related Collective Action. Beta 1.0. Prepared by Pacific Institute, Ross Strategic, Pegasys Strategy and Development, and Water Futures Partnership. Oakland, CA, USA. Retrieved from http://ceowatermandate.org/files/guide_to_collective_action.pdf

CEO Water Mandate. (2012). Guide to Water-Related Collective Action. Beta 1.0 August 2012. Prepared by Pacific Institute, Ross Strategic, Pegasys Strategy and Development, and Water Futures Partnership. Oakland, CA, USA: Pacific Institute. Retrieved from http://www.pacinst.org/reports/water_related_collective_action/wrca_full_report.pdf

Intergovernmental Panel on Climate Change, Climate Change. (2007). Synthesis Report, Fourth Assessment Report. Retrieved November 27, 2012, from http://www.ipcc.ch/publications_and_data/ar4/syr/en/contents.html

United Nations Resolution 64/292, The Human Right to Water and Sanitation. Retrieved from http://www.un.org/ga/search/view_doc.asp?symbol=A/RES/64/292

United States Department of Agriculture. (1986). Urban hydrology for small watersheds. Technical Release 55 (TR-55) (2nd ed.). Natural Resources Conservation Service, Conservation Engineering Division.

United, Nations, Office of the High Commissioner for Human Rights, A/HRC/17/31, Report of the Special Representative of the Secretary-General on the issue of human rights and transnational corporations and other business enterprises, John Ruggie, Guiding Principles on Business and Human Rights: Implementing the United Nations "Protect, Respect and Remedy" Framework. Retrieved from http://www.ohchr.org/EN/Issues/TransnationalCorporations/Pages/Reports.aspx

USDA Agricultural Research Service and Texas A\&M University, Soil \&Water Assessment Tool. Retrieved from http://swat.tamu.edu/

World Economic Forum's Water Resource Group 2030. (2009). Charting our Water Future: Economic Frameworks to Inform Decision Making. Retrieved November 27, 2012, from http://www.2030wrg.org/wp-content/uploads/2012/06/Charting_Our_Water_Future_Final.pdf

\section{Note}

Note 1. Consumptive useincludes water losses within industrial and manufacturing processes (e.g., cooling towers and other evaporative water losses) and the water content in the manufactured good (e.g., beverages). 
Addendum 1. Sustainable Water Balance-Strategy and Implementation Decision Support Matrix (Rozza, J.P., 2012)

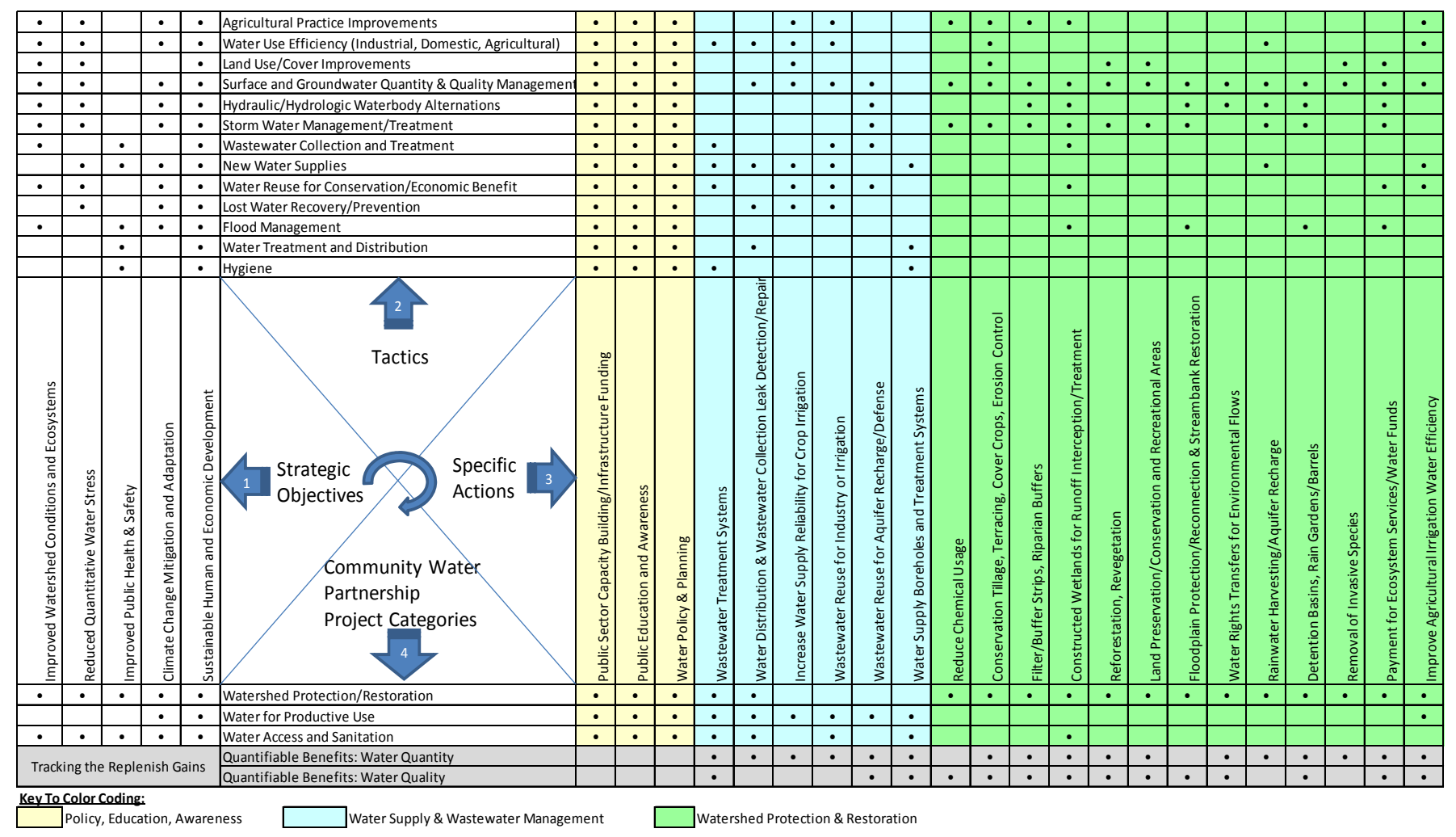

Guidance on Using the Matrix:

Step 1 Define strategic objectives based on water risk assessments, community/government engagement, business strategy and partner priorities

Step 2 Determine tactical priorities based on priority of concerns, available resources, stakeholder interest and implementation capabilities

Step 3 Select specific project for implementation

Step 4 Classify project by type, determine if has quantifiable benefits and use Table 1 to select quantification method

\section{Copyrights}

Copyright for this article is retained by the author(s), with first publication rights granted to the journal.

This is an open-access article distributed under the terms and conditions of the Creative Commons Attribution license (http://creativecommons.org/licenses/by/3.0/). 